\title{
A rapid and inexpensive one-tube genomic DNA extraction method from Agrobacterium tumefaciens
}

\author{
Suresh P. Kamble • Madhukar M. Fawade
}

Received: 28 January 2013/ Accepted: 19 March 2013/Published online: 28 April 2013

(C) The Author(s) 2013. This article is published with open access at Springerlink.com

\begin{abstract}
Many methods have been used to isolate genomic DNA, but some of them are time-consuming and costly, especially when extracting a large number of samples. Here we described an easy protocol using two simple solutions for DNA extraction from A. tumefaciens cells. Compared with the standard protocol, this protocol allows rapid DNA isolation with comparable yield and purity at negligible cost. Following this protocol, we have demonstrated: (1) gDNA extraction was achieved within $15 \mathrm{~min}$; (2) this method was cost-effective, since it only used calcium chloride and lysozyme; SDS, phenol, chloroform and proteinase $\mathrm{K}$ were not necessary; (3) the method gave high yield of gDNA (130 ng/loopful culture) compared with standard protocol that was suitable for restriction analysis; (4) the protocol can be carried out in a single test tube and the cells directly from solid media can be used. Thus, this protocol offers an easy, efficient and economical way to extract genomic DNA from A. tumefaciens.
\end{abstract}

Keywords Genomic DNA extraction - Restriction digestion $\cdot$ Calcium chloride $\cdot$ Lysozyme

\section{Abbreviations \\ gDNA Genomic DNA \\ LB Luria Bertani broth}

S. P. Kamble $(\bowtie)$

Center for Biotechnology, Pravara Institute of Medical Sciences, Loni, Ahmednagar, Maharashtra, India

e-mail: suresh.kamble@pmtpims.org

M. M. Fawade

Department of Biochemistry, Dr. Babasaheb Ambedkar

Marathwada University, Aurangabad 411004,

Maharashtra, India
kbp Kilo base pairs
$\mathrm{CaCl}_{2} \quad$ Calcium chloride
TE Tris-EDTA
TAE Tris-acetate EDTA

\section{Introduction}

To study the molecular systematics of any organism, high quality DNA is required. The rapid availability of genomic DNA is necessary for cloning genes, selecting recombinant constructs and for taxonomy (Niemi et al. 2001). The cell wall is the main obstacle for quick and easy lysis of Agrobacterium cells, and therefore, it must be disrupted for efficient recovery of genomic DNA (gDNA). Conventional methods for gDNA preparation from Agrobacterium utilize either enzymatic degradation followed by lysis of cells with detergent or extraction of gDNA with phenol-chloroform (Charles and Nester 1993). When analyzing a large number of samples, these methods are time-consuming and relatively expensive. For quick genotyping, cells can also be lysed by repeated freeze-thaw cycles in a buffer containing Triton X-100 and SDS, followed by extraction of gDNA with chloroform (Harju et al. 2004; Smith and Cantor 1987). Although this method gives good yield, it requires transfer of the sample to a new eppendorf tube after chloroform extraction, which slows down the protocol and makes it inconvenient for simultaneous handling of large number of samples. The above method gives relatively low yield and the results are poorly reproducible. In addition, a large number of cells are required for the protocol.

As calcium chloride is used commonly in Agrobacterium transformation protocol to weaken cell walls (McCormack et al. 1998; Mattanovich et al. 1989), we decided to

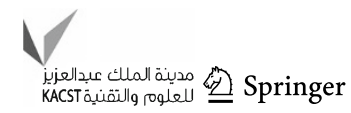


combine it with lysozyme to develop a quick, efficient and robust method for gDNA extraction from Agrobacterium.

\section{Materials and methods}

Culture maintenance and growth conditions

Agrobacterium tumefaciens strain $\mathrm{C} 58 \mathrm{C} 1$ was grown on LB agar plates $(10 \mathrm{~g} / \mathrm{L}$ tryptone, $5 \mathrm{~g} / \mathrm{L}$ yeast extract, $10 \mathrm{~g} /$ $\mathrm{L} \mathrm{NaCl}, \mathrm{pH} 7.2$, and $15.0 \mathrm{~g} / \mathrm{L}$ agar) for $24 \mathrm{~h}$ at $28{ }^{\circ} \mathrm{C}$. For gDNA isolation, $48 \mathrm{~h}$ culture was used. And for isolation of gDNA from liquid culture, A. tumefaciens cells were grown overnight at $28{ }^{\circ} \mathrm{C}$ at $200 \mathrm{rpm}$ in LB medium $(10 \mathrm{~g} /$ $\mathrm{L}$ tryptone, $5 \mathrm{~g} / \mathrm{L}$ yeast extract, $10 \mathrm{~g} / \mathrm{L} \mathrm{NaCl}, \mathrm{pH}$ 7.2). $3 \mathrm{ml}$ culture was used.

\section{DNA isolation}

Eight to ten single colonies of A. tumefaciens were picked up from LB plate, suspended in $100 \mu \mathrm{L}$ of $200 \mathrm{mM} \mathrm{CaCl}_{2}$ and $1 \%$ lysozyme and incubated at $42{ }^{\circ} \mathrm{C}$ for $2-5 \mathrm{~min}$. After incubation, $300 \mu \mathrm{L}$ of $96 \%$ ethanol was added; the samples were mixed briefly by vortexing; and DNA was collected by centrifugation at 13,200 rpm for $5 \mathrm{~min}$. Precipitated DNA was air dried at room temperature for $10 \mathrm{~min}$ and dissolved in $50 \mu \mathrm{L} \mathrm{TE}$; cell debris was spun down by brief centrifugation at 12,000 rpm for $2 \mathrm{~min}$ and supernatant containing purified DNA was directly used for the subsequent experiments or stored at $-20^{\circ} \mathrm{C}$.

\section{Quantification}

The purity and yield of gDNA were assessed spectrophotometrically by calculating the $A_{260} / A_{280}$ and $A_{260} / A_{230}$ ratios and $A_{260}$ values to determine protein impurities and DNA concentration.

\section{Restriction analysis}

To test whether the gDNA prepared using this method could be digested with restriction enzyme, 1-2 $\mu \mathrm{g}$ of gDNA from A. tumefaciens was incubated with 5U EcoRI in a final volume of $20 \mu \mathrm{L}$ for $2 \mathrm{~h}$ at $37{ }^{\circ} \mathrm{C}$ and applied to $1 \%$ agarose gel electrophoresis.

\section{Results and discussion}

In the recommended DNA extraction protocol, A. tumefaciens cells were lysed by calcium chloride along with lysozyme without the use of phenol, Triton X-100. Since calcium chloride is used to weaken the cell wall and lysozyme to break up the cell wall (Ledeboer et al. 1976; Chassy 1976; Chassy and Giuffrida 1980), it could directly loose and disrupt the cell wall or nucleus envelop and gDNA was released from the cells. The released gDNA was directly precipitated using $96 \%$ ethanol, omitting phenol chloroform extraction step. This method gave reproducible yields of high quality DNA (Table 1). We also compared our results with the standard method of gDNA extraction protocol (Slusarenko 1990). The obtained genomic DNA by our method and standard method was run in $0.8 \%$ TAE-agarose gel (Fig. 1).

Next, we optimized the protocol to find out the critical components for effective DNA extraction by $\mathrm{CaCl}_{2}-\mathrm{lyso}$ zyme lysis method. We tested different concentrations of $\mathrm{CaCl}_{2}$ and lysozyme in the lysis solution (data not shown). We also used the different incubation time ranges from 2 to 5 min (data not shown). To summarize, we recommend using $200 \mathrm{mM} \mathrm{CaCl} 2$ and $1 \%$ lysozyme in the lysis solution and carrying the lysis at $42{ }^{\circ} \mathrm{C}$ for $3 \mathrm{~min}$.

We used the gDNA prepared by our method for restriction digestion. The restriction digestion pattern of gDNA clearly showed that gDNA obtained could be digested by EcoRI (Fig. 2). The size of most digested gDNA fragments ranged from 23.13 to $0.5 \mathrm{kbp}$, while the size of control DNA (lane no. 4 in Fig. 2 and lane no. 2 in Fig. 1) corresponded to more than $23 \mathrm{kbp}$ (Fig. 1). Hence DNA was completely digested and there was no evidence of the presence of nucleases in the sample.

Table 1 Yield and quality of DNA obtained from Agrobacterium using recommended method

\begin{tabular}{llll}
\hline Method & $\begin{array}{l}\text { Mean DNA } \\
\text { yield (ng/ml) }\end{array}$ & $\begin{array}{l}A_{260} / \\
A_{280}\end{array}$ & $A_{260 / 230}$ \\
\hline Standard method & $150 \pm 0.400$ & 1.72 & 2.185 \\
Recommended method & $130 \pm 0.325$ & 1.65 & 1.988 \\
\hline
\end{tabular}

Fig. 1 Genomic DNA isolated from Agrobacterium by standard and recommended method. M-HindIII digested Lambda DNA as marker; L1-Genomic DNA isolated by standard method; L2-Genomic DNA isolated by recommended method

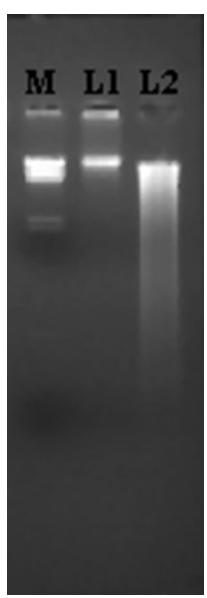




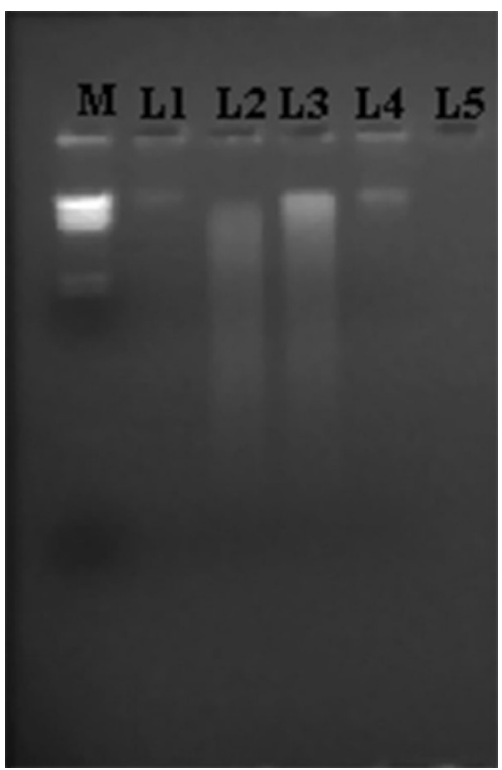

Fig. 2 Agarose gel electrophoresis of EcoRI restriction digestion reaction of gDNA by standard and recommended method. M-HindIII digested Lambda DNA as marker; L1-uncut DNA from standard method; L2-digested DNA from standard method; L3-digested DNA from recommended method; L4-Uncut DNA obtained by recommended method; and L5-blank

We repeated the restriction digestion experiment over a period of 1-2 months and obtained the same banding pattern which indicated the reproducibility of the results and integrity of the gDNA (Ellsworth et al. 1993).

These restriction digestion results show that no restriction process was inhibited by any components in the DNA preparation. This gDNA extraction method has several advantages. First, the numbers of extraction steps were minimized so the gDNA extraction was achieved within $15 \mathrm{~min}$, while other methods needed at least 5-30 min. Second, the method gave high yield of gDNA compared with standard protocol. Third, this method was costeffective, since it only uses calcium chloride and lysozyme. $\mathrm{SDS}$, phenol, chloroform and proteinase $\mathrm{K}$ were not necessary. Fourth, the protocol can be carried out in a single test tube and the cells directly from solid media cab be used.

\section{Conclusions}

We have developed a quick and reliable method for gDNA extraction from Agrobacterium that is suitable for restriction digestion. The protocol can be carried out in a single eppendorf tube $<15 \mathrm{~min}$ and directly from the cells. Finally, it can be used for sequencing, PCR and blotting techniques.

Acknowledgments The authors would like to thank the authorities of Pravara Institute of Medical Sciences (DU), Loni for providing the facilities.

Open Access This article is distributed under the terms of the Creative Commons Attribution License which permits any use, distribution, and reproduction in any medium, provided the original author(s) and the source are credited.

\section{References}

Charles TC, Nester EW (1993) A chromosomally encoded twocomponent sensory transduction system is required for virulence of Agrobacterium tumefaciens. J Bacterio 175:6614-6625

Chassy BM (1976) A gentle method for the lysis of oral Streptococci. Biochem Biophys Res Commun 68:603-608

Chassy BM, Giuffrida A (1980) Method for the lysis of grampositive, Asporogenous bacteria with lysozyme. Appl Environ Microbiol 39(1):153-158

Ellsworth DL, Rittenhouse D, Honeycutt RL (1993) Artificial variation in randomly amplified polymorphic DNA banding patterns. BioTechnique 14:214-218

Harju S, Fedosyuk H, Peterson KR (2004) Rapid isolation of yeast genomic DNA: burst n' grab. BMC Biotechnol 4:8

Ledeboer AM, Krol AJ, Dons JJ, Spier F, Schilperoort RA, Zaenen I, Van Larebeke N, Schell J (1976) On the isolation of TI-plasmid from Agrobacterium tumefaciens. Nucleic Acids Res 3(2):449-463

Mattanovich D, Rüker F, Machado AC, Laimer M, Regner F, Steinkuehler H, Himmler G, Katinger H (1989) Efficient transformation of Agrobacterium spp. by electroporation. Nucleic Acids Res 17(16):6747

McCormack AC, Elliott MC, Chen DF (1998) A simple method for the production of highly competent cells of Agrobacterium for transformation via electroporation. Mol Biotechnol 9(2):155-159

Niemi RM, Heiskanen I, Wallenius K, Lindstrom K (2001) Extraction and purification of DNA in rhizosphere soil samples for PCRDGGE analysis of bacterial consortia. J Microbiol Methods 45:155-165

Slusarenko AJ (1990) A rapid mini prep for the isolation of total DNA from Agrobacterium tumefaciens. Plant Mol Biol Rep 8(4):249-252

Smith CL, Cantor CR (1987) Purification, specific fragmentation, and separation of large DNA molecules. Methods Enzymol 155:449-467 